\title{
Scrophularia amadiyana (Scrophulariaceae), a new species from Iraq and a key to Scrophularia in Iraq
}

\author{
Shahina A. Ghazanfar ${ }^{1}$ \& Ali Haloob ${ }^{2}$
}

Summary. A new species, Scrophularia amadiyana is described and illustrated. It resembles S. gracilis Blakelock in habit but can be differentiated by its glandular-pubescent, oblong calyx lobes which are without scarious margins, smaller glandular capsules and seeds that are longitudinally ridged and obscurely pitted. The species is known so far from a single location in Iraq growing on mountain slopes in Kurdistan where it is reported to be frequent, and is assessed here as Data Deficient.

Key Words. conservation, endemic, Iran, Kurdistan, taxonomy, Turkey.

\section{Introduction}

Scrophularia is large genus of about 200 species distributed mainly in Asia, Europe and N America. Al-Rawi in his list of plants of Iraq (1964) recorded 19 species of Scrophularia and Grau (1981) described 17 species from Kurdistan Iraq (area covered by Flora Iranica). For the Flora of Iraq volume 7, the first author has recognised 17 species from Iraq (including the new species described in this paper), all found in the mountains and upper plains of northern Iraq with the exception of a single species, S. hypericifolia Wydler, which is found on the desert plains in southern Iraq (Ghazanfar, in prep.).

The majority of the species of Scrophularia found in Iraq are also found in the countries bordering Iraq, viz Turkey (Lall \& Mill 1978; Dönmez \& Uğurlu 2010), Iran (Grau 1981; Attar 2011) and Saudi Arabia (Chaudhary 2001). A few Iraqi species have a wider distribution: eastwards to Pakistan and northern India and westwards to Jordan, Palestine and Egypt and northwards to Armenia and Russia (Feinbrun-Dothan 1978; Gorschk 1994; Boulos 2002; Qaiser et al. 2015). Of the 17 species found in Iraq three are endemic to northern Iraq (Kurdistan) and two are near endemics found on the border areas of E Turkey and NW Iran.

Scrophularia was the subject of Al-Sawah's research (1982, unpublished) where he described this and two other taxa new to science. After careful study, we found that, apart from one taxon, described here as a new species, the others were not good species and could be placed under the already known taxa of Scrophularia in Iraq. Al-Sawah's new taxa are reviewed, and a key to the known species in Iraq is provided.

Scrophularia amadiyana Ghaz. Eं Haloob sp. nov. Type: Iraq, Dohuk Province, Gali Mazurka, $2 \mathrm{~km} \mathrm{NW}$ Amadiyah, Al-Dabbagh $\mathcal{E}$ M. Jasim 46915 (holotype $\mathrm{BAG}$ !; isotype $\mathrm{K}$ !).

http:/ /www.ipni.org/urn:lsid:ipni.org:names:60473796-2

Scrophularia amatiana Al-Sawah nom. nud., ined.

Perennial herb. Stems simple, 10 - $150 \mathrm{~mm}$, erect, weekly 4-angled, densely glandular-hairy. Leaves alternate; petiole $3-5 \mathrm{~mm}$; lamina broadly ovate to reniform or suborbicular, $8-10 \times 6-12 \mathrm{~mm}$, base rounded to cuneate, margins dentate, densely glandular-puberulent on both surfaces. Inflorescence leafy; cymes 1 - 2-flowered; bracts lower and middle with petioles $0.5-3 \mathrm{~mm}$, the upper sessile to shortly petiolate; lower bracts reniform to ovatesuborbicular, $6.5-10 \times 5.5-8.5 \mathrm{~mm}$, base cuneate and tapering into the petiole, apex rounded, margins irregularly dentate; middle bracts ovate to

\footnotetext{
Accepted for publication 7 February 2017. Published online 4 April 2017

1 Royal Botanic Gardens, Kew, Richmond, Surrey, TW9 3AB, UK. e-mail: s.ghazanfar@kew.org

2 National Herbarium of Iraq, Ministry of Agriculture, Al Gharaib, Republic of Iraq.
} 
ovate lanceolate, $6-8.5 \times 4-7 \mathrm{~mm}$, base tapering, apex acute, margins entire; upper bracts similar to middle bracts but smaller, $3 \times 1.5-2 \mathrm{~mm}$; all bracts densely glandular-puberulent; bracteoles linear, $2-3 \times 1 \mathrm{~mm}$ long; peduncles $6-6.5 \mathrm{~mm}$, glandular-hairy; pedicels $2-3 \mathrm{~mm}$, almost equalling bracteoles, glandular-hairy. Calyx lobes oblong, $3.5-4 \mathrm{~mm}$, acute to obtuse, without scarious margins, glandular on both surfaces. Corolla purple to dark red, $7-9 \mathrm{~mm}$; corolla tube oblong, ventricose, narrowing at apex to $1.5 \mathrm{~mm}$, wider in the middle and base to about $2 \mathrm{~mm}$; lobes $\pm 1 \mathrm{~mm}$, subequal, upper and lateral lobes orbicular, median broadly ovate, smaller than the upper lobe. Stamens 4 , as long as or slightly longer than the corolla tube; filaments glandular-pubescent; anthers dorsifixed; staminode absent. Style slender, persisting in fruit; stigma capitate. Capsule globose, $3.5-4 \times 3.5-4 \mathrm{~mm}$, apiculate, glandularpubescent, dehiscence septicidal. Seeds oblong, 0.9 - $1.3 \times 0.4-0.6 \mathrm{~mm}$, longitudinally ridged and obscurely pitted. Fig. 1.

RECOGNITION. The new species is closely related to Scrophularia gracilis Blakelock described from Iraq, but differs in its oblong calyx lobes that are without scarious margins and glandular on both surfaces, smaller, glandular-pubescent capsules, and longitudinally ridged, obscurely pitted seeds (vs ovate calyx lobes with white scarious margins, larger $(5-6 \mathrm{~mm})$ glabrous capsules and distinctly pitted seeds in $S$. gracilis). S. amadiyana is also similar to $S$. kotschyana Benth. described from Turkey, also found in Georgia, but differs its erect habit, smaller, densely glandular-puberulent leaves with small petioles and 1 - 2-flowered cymes (vs a prostrate to suberect habit, larger \pm glabrous leaves (23 - $65 \mathrm{~mm}$ ), longer petioles (to $14 \mathrm{~cm}$ ), and 3 5-flowered cymes in S. kotschyana).

DISTRIBUTION. Known from northern Iraq, from the Upper Jazira District (type collection only).

SPECIMENS EXAMINED. Northern Iraq, Dohuk Province: Gali Mazurka, 2 km NW Amadiyah, 1700 m, 1 June 1977, Al-Dabbagh $\mathcal{E}$ M. Jasim 46915 (holotype $\mathrm{BAG}$; isotype $\mathrm{K}$ ).

HABITAT. Rocky mountain slopes; alt. $\pm 1700 \mathrm{~m}$.

CONSERVATION STATUS. Endemic. So far known from a single locality where it is apparently frequent (fide Al-Dabbagh $\mathcal{E}^{2}$ M. Jasim 46915). Since no other collections are present at BAG or $\mathrm{K}$, it is difficult to assess its conservation status. Owing to the difficulty of carrying out field work in northern Iraq, we currently assess it as Data Deficient (DD - IUCN 2001). However, with more field work this status is likely to change. The location where this species has been collected is heavily grazed and continues to be so; in addition the town of Amadiyah has greatly expanded with new roads and other development since the 1970's when this collection was made (Haloob, pers. obs.). It is possible that this species may have become extinct from the type locality or would be under considerable pressure from urban expansion.

PHENOLOGY. June (as given on the plant label), but probably flowers and fruits from June - July as do most of the other herbaceous perennials in this region at this altitude in Iraq.

ETYMOLOGY. Scrophularia amadiyana is named after the town of Amadiyah in northern Iraq, from near where it was collected.

NOTES. Scrophularia amadiyana falls within a group of species with long, somewhat ventricose corolla tubes $(\geq 7 \mathrm{~mm})$, such as $S$. catariifolia Boiss., found in Turkey and Iran, and $S$. gracilis found in NE Turkey. In Iraq, species of Scrophularia can be distinguished by their basal leaves from being pinnatisect to deeply lobed to ovate to lanceolate, and with margins dentate or entire; inflorescence, whether with 1 - 2-flowered cymes or multiflowered thyrses is also a good character to distinguish taxa. Variations, however, are present in both leaf and inflorescence characters in several of the species, but then, coupled with other characters such as indumentum, structure of calyx and corolla are used satisfactorily to distinguish taxa. As with most taxa in Iraq, those with a wide distribution range, spanning several countries and different habitats tend to be more variable in vegetative characters such as those of leaf shape and lobation, than those with a narrow distribution range. This is true for the two species described as new by Al-Sawah, S. sinjariflora Al-Sawah ined. (Jabal Sinjar, Sawah 81.64 BUH - type of $S$. sinjariflora), and $S$. rafidainsis Al-Sawah ined. (Raqaba above Sharanish, Sawah E M Musawi 44256 BUH - type of S. rafidainsis, \& ibid., Sawah 44255 BUH). After examining the material, I (SAG) considered $S$. sinjariflora the same as $S$. striata Boiss. falling within the range of the variations seen in S. striata. S. striata is a widespread and variable species, found from Russia, Turkey, Iraq and Iran to Pakistan. It is well represented in Iraq, found on the mountains and foothills from $450-1800 \mathrm{~m}$. Sawah separated his taxon on the basis of its robust habit and multiflorous thyrse, both characters probably influenced by habitat, but also found to have considerable variation in S. striata in Iraq.

Scrophularia rafidainsis was separated by Al-Sawah on its biennial habit, glabrous stems and glandular 3 - 7-flowered cymes, which I have placed under S. macrophylla Boiss., another widely distributed species found in Turkey, Syria, Palestine, Lebanon and Jordan. S. macrophylla too is variable in its leaf and inflorescence characters, which, together with 


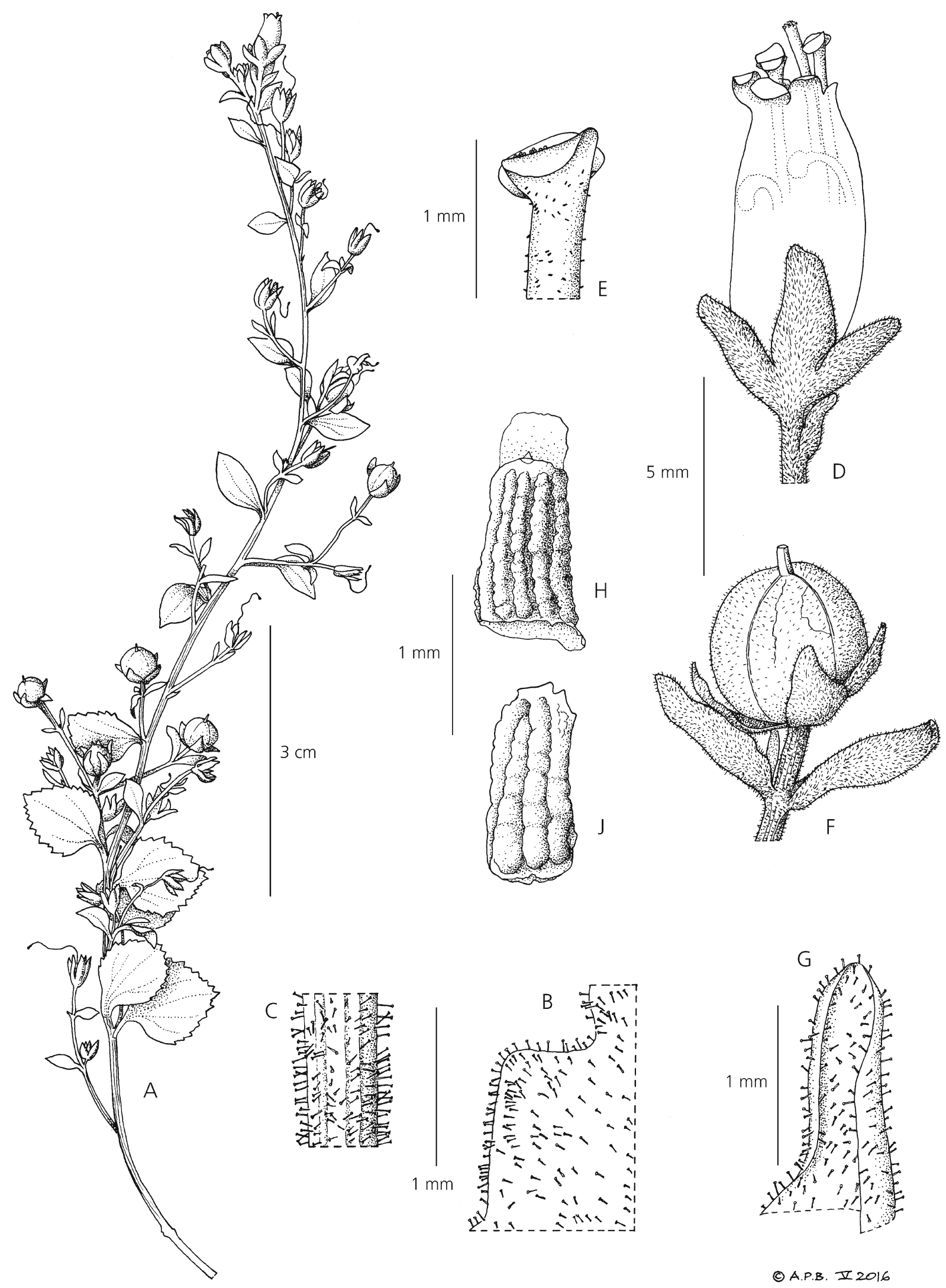

Fig. 1. Scrophularia amadiyana. A habit; B, indumentum on leaf (abaxial surface and margin); C indumentum on stem; D flower (showing two anthers inside tube - flower too tightly affixed for removal and hydration); $\mathrm{E}$ anther and distal portion of filament; $\mathrm{F}$ capsule with calyx and bracteoles; G tip of calyx lobe showing indumentum on outer and inner surfaces; H \& J seeds. All from Al-Dabagh \& Jassim 46915. DRAWNBYA.P. BROWN. 
other related species ( $S$. chlorantha Kotschy \& Boiss., S. scopolii Hoppe ex Pers. var. scopolii and S. guestii Eig) form a complex of species distributed from the Caucasus to Iran and Syria, Lebanon and
Palestine, and are difficult to separate satisfactorily. They require a thorough study of their ecology and molecular phylogeny, from which S. rafidainsis may prove to be a new taxon.

\section{Key to the species of Scrophularia in Iraq}

1. Basal leaves deeply lobed, incised or pinnatilobed $\ldots \ldots \ldots \ldots \ldots \ldots$

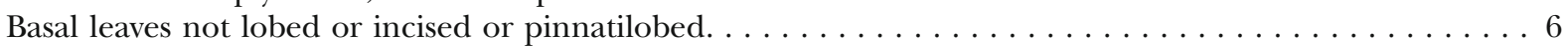

2. Plant glaucous, to $100 \mathrm{~cm}$ with \pm rigid, erect stems; calyx lobes oblong to oblong-obovate, $2-3 \mathrm{~mm}$; corolla dark purplish red, to $5 \mathrm{~mm}$, the upper lobes narrower at base; staminode white, as large as the upper corolla

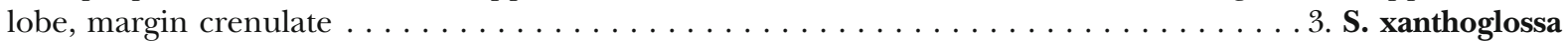

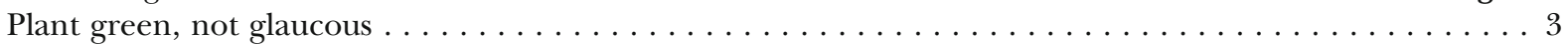

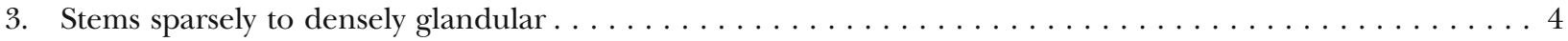

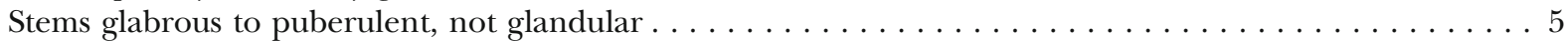

4. Cymes 5 - 7-flowered, sparsely glandular; calyx lobes glabrous; staminal filaments glabrous . . . . . 4. S. sulaimanica Cymes 1 - 2-flowered, glandular; calyx lobes with sessile glands at base (sometimes glabrous especially in fruit); staminal

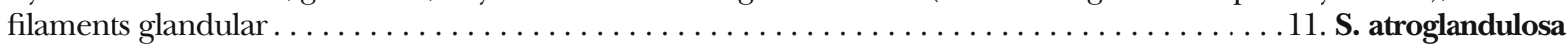

5. Young and flowering branches glabrous, not appearing zigzag; pedicels $1-2 \mathrm{~mm}$, glabrous; staminode smaller

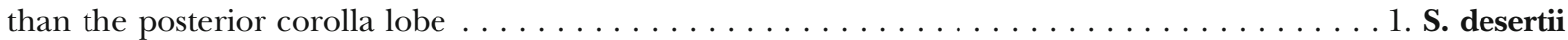
Young and flowering branches glabrous to puberulent appearing zig-zag; pedicels 2 - 3 mm, minutely puberulent; staminode about as long as the posterior corolla lobe . . . . . . . . . . 2. S. striata

6. Stems and branches white to greyish white, smooth, stout, branching divaricately, the lower spreading, the upper erect to erect-horizontal; lateral branches becoming spinescent . . . . . . . . . 17. S. hypericifolia Stems and branches dark brown to greenish brown, branched but not divaricate, laterals not becoming

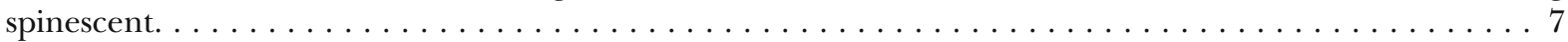

7. Plant villous; leaves villous on both surfaces or sometimes the lower surface sparsely villous to glabrous.... 13. S. pegaea

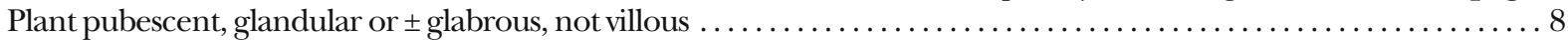

8. Plant densely glandular throughout, especially the leaves and lower parts of stem . . . . . . . . . 9 Plant in part pubescent, glandular or almost glabrous, never densely glandular $\ldots \ldots \ldots \ldots$

9. Basal and lower leaves subreniform to ovate-orbicular $\ldots \ldots \ldots \ldots \ldots \ldots$

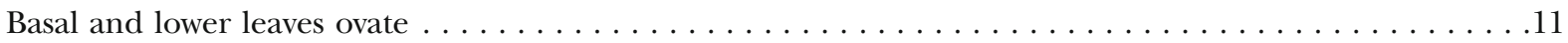

10. Leaves $10-25 \times 8-20 \mathrm{~mm}$; petiole 5 - $10 \mathrm{~mm}$; cymes 3 - 7-flowered; capsule glabrous . . . 15. S. gracilis Leaves 8-10×6-12 mm, petiole 3-5 mm; cymes 1-2-flowered; capsule glandular-pubescent .... 16. S. amadiyana

11. Glands distinctly white (in Iraq plants); fruiting pedicel of central flower in cyme stout, 3 - 5 mm,

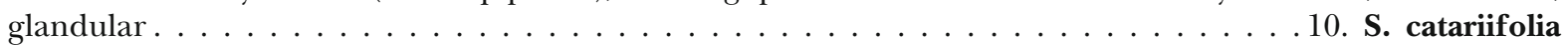
Glands brown; fruiting pedicel of central flower in cyme not stout. . . . . . . . . . . . . 12

12. Stems white pruinose and glandular; flowers 5-11 in lax cymes (sometimes with lateral branches developing in one plane, alternately in opposite directions, the main axis appearing zig-zag); pedicel 1 $3 \mathrm{~mm} \ldots \ldots \ldots \ldots \ldots \ldots \ldots \ldots \ldots \ldots \ldots \ldots$. . . . . . . . . . . . . . . . . . . . . . . . . . . . . . . . . . . . . . . Stems glandular-pubescent; lower cymes 8 - 25-flowered, upper 2 - 5-flowered, never appearing zig zag; pedicel $15 \mathrm{~mm} \ldots \ldots \ldots \ldots \ldots \ldots \ldots \ldots \ldots \ldots$. . . . . . . . . . . . . . . . . . . . . . . . . . . . . . . . . . . . .

13. Stems and leaves glabrous; stems distinctly quadrangular, narrowly winged . . . . . . . . 6. S. umbrosa Plants glabrous to obscurely puberulous or glandular; stems not distinctly quadrangular, nor winged . . . . . . . 14

14. Stems and leaves dark green; leaves sessile to very shortly petiolate $\ldots \ldots \ldots \ldots \ldots$. . . . . . . . kurdica

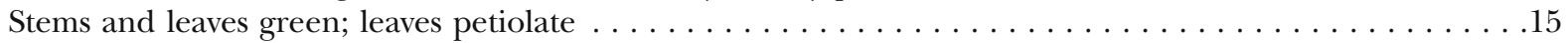

15. Leaves lanceolate $35-65 \times 5-12 \mathrm{~mm}$; peduncles and pedicels pruinose to glandular $\ldots \ldots$. . S. nervosa Leaves ovate to ovate-oblong (or sometimes pinnatipartite), wider than $5 \mathrm{~mm} \ldots \ldots \ldots$

16. Large herb to $1 \mathrm{~m}$; leaves ovate to ovate-oblong, $20-90 \times 13-60 \mathrm{~mm}, \pm$ glabrous . . . . 7. S. macrophylla Herb to $60 \mathrm{~cm}$; leaves ovate, $10-45 \times 8-25 \mathrm{~mm}$, gradually reduced in size upwards, glabrous . . . .5. S. libanotica 


\section{Acknowledgements}

The authors thank the two anonymous reviewers for making helpful suggestions on an earlier version of this paper.

Open Access This article is distributed under the terms of the Creative Commons Attribution 4.0 International License (http://creativecommons.org/ licenses/by/4.0/), which permits unrestricted use, distribution, and reproduction in any medium, provided you give appropriate credit to the original author(s) and the source, provide a link to the Creative Commons license, and indicate if changes were made.

\section{References}

Al-Rawi, A. (1964). Wild plants of Iraq with their distribution. Techn. Bull. Ministry of Agriculture 14: 144- 145.

Al-Sawah, Diab Abid M. (1982, unpublished). A systematic study of the genus Scrophularia (Scrophulariaceae) in Iraq. University of Baghdad, Iraq. Unpublished MSc thesis.

Attar, F. (2011). Scrophularia. In: M. Assadi, A. A. Maassoumi, P. Babakhanlou \& V. Mozaffarian (eds), Fl. Iran 68: 206 - 307. Research Institute of Forests and Rangeland, Republic of Iran.

Boulos, L. (2002). Flora of Egypt 3: 70 - 73. Hadara Publishers, Cairo.
Chaudhary, M. (2001). Flora of the Kingdom of Saudi Arabia 2 (2): 446 - 447. Ministry of Agriculture and Water, Riyadh.

Dönmez, A. A. \& Uğurlu, Z. (2010). Scrophularia gracilis Blakelock (Scrophulariaceae): a new record for the flora of Turkey. Biol. Diversity $\mathcal{E}^{\circ}$ Conservation 3: $72-74$.

Feinbrun-Dothan, N. (1978). Flora Palaestina 3: 194 - 200. Israel Academy of Sciences, Jerusalem.

Ghazanfar, S. A. (in prep.). Scrophularia. In: S. A. Ghazanfar \& J. R. Edmondson (eds), Flora of Iraq, Vol. 7. Royal Botanic Gardens, Kew.

Gorschk, S. G. (1994). Scrophularia. In: V. L. Komarov (ed.), Flora of the USSR Vol. 22, Solanceeae A. L. Jussieu and Scrophulariaceae A. L. Jussieu: 264. Bishen Singh Mahendra Pal Singh, Dehra Dun and Koeltz, Koenigstein.

Grau, J. (1981). Scrophularia. In: K. H. Rechinger (ed.), Fl. Iranica 147: 213 - 284. Akademische Druck- u. Verlagsanstalt, Graz.

IUCN (2001). IUCN Red List Categories and Criteria: Version 3.1. IUCN Species Survival Commission. IUCN, Gland and Cambridge.

Lall, S. S. \& Mill, R. R. (1978). Scrophularia. In: P. H. Davis (ed), Flora of Turkey 6: 603 - 647. Edinburgh University Press, Edinburgh.

Qaiser, M., Khatoon, S. \& Hamidullah (2015). Scrophularia. In: S. I. Ali \& M. Qaiser (eds), Flora of Pakistan 220: 234 - 258. Centre for Plant Conservation, Karachi University, Karachi. 